\title{
Rasmussen's Encephalitis. A Case Report
}

\author{
Encefalitis de Rasmussen. Reporte de Caso
}

\author{
Tania Soledad Licona Rivera*; Alejandra Mazariegos-Rivera** \& Morgan Medina***
}

LICONA, R. T. S.; MAZARIEgOS-RIVERA, A. \& MEDINA, M. Rasmussen's encephalitis. A case report. Int. J. Med. Surg. Sci., 3(2):849-854, 2016.

SUMMARY: Rasmussen's encephalitis (RE) is a rare but severe immune-mediated brain disorder leading to unilateral hemispheric atrophy, associated progressive neurological dysfunction with intellectual decline, and intractable seizures. It is a well-established cause of pharmacologically intractable epilepsy. The report is on a 17-month-old infant, treated at the Mario Catarino Rivas Hospital Honduras. Family history: grandfather epileptic secondary trauma from 20 years. Personal history: two previous emergency visits (at 16 months and 16 months 8 days) for convulsions for which she was admitted three days and was treated with valproic acid $30 \mathrm{mg} / \mathrm{kg}$ per day. The infant is admitted in the emergency, with a history of about three hours after onset of tonic convulsions, focused on left-side with drooling, oculogiros and relaxation of sphincters and fever of $38.5^{\circ} \mathrm{C}$. Entered as convulsive syndrome in the study, however, as the days passed the number of seizures increased to 60 per day and was gradually presenting alterations in neurodevelopment. MRI reported leukoencephalopathy of undetermined origin and biopsy reported findings consistent with Rasmussen's syndrome. She was treated with immunoglobulin every two weeks for six doses after two months of hospitalization with achieved improvement. Currently, episodes of seizures have decreased significantly and almost not convulsing, she presented alterations in neurodevelopment.

KEY WORDS: Biopsy; Encephalitis; Epilepsies Partial; Seizures.

\section{INTRODUCTION}

Rasmussen's encephalitis (ER) is a focal and chronic condition described in 1958 by Theodore Rasmussen (Carmona-Vázquez et al., 2014), it is a rare but severe immune-mediated brain disorder leading to unilateral hemispheric atrophy, associated progressive neurological dysfunction with intellectual decline, and intractable seizures. It is a well-established cause of pharmacologically intractable epilepsy (O'Rourke et al., 2014).

The mechanisms of epileptogenesis in pediatric epileptic syndromes are diverse, and may involve disturbances of neurodevelopmental trajectories, synaptic homeostasis, and cortical connectivity, which may occur during brain development, early infancy, or childhood. Although genetic or structural/metabolic factors are frequently associated with age-specific epileptic syndromes, such as infantile spasms and West syndrome, other syndromes may be determined by the effect of immunopathogenic mechanisms or energy-dependent processes in response to environmental challenges, such as infections or fever in normally-developed children during early or late childhood. Immune-mediated mechanisms have been suggested in selected pediatric epileptic syndromes in which acute and rapidly progressive encephalopathies preceded by fever and/or infections, such as febrile infection-related epilepsy syndrome, or in chronic progressive encephalopathies, such as

\footnotetext{
* Doctora en Medicina General y Cirugía, Especialidad en Pediatría. Universidad Nacional Autónoma de Honduras en el Valle de Sula, San Pedro Sula, Honduras.

** Doctora en Medicina General y Cirugía, San Pedro Sula, Honduras.

*** Neurólogo Pediatra. Hospital Mario Catarino Rivas, San Pedro Sula, Honduras.
} 
Rasmussen encephalitis (Pardo et al., 2014). Neuropathological and immunological studies support the notion that Rasmussen's encephalitis is probably driven by a T-cell response to one or more antigenic epitopes, with potential additional contribution by autoantibodies. Careful analysis of the association between histopathology and clinical presentation suggests that initial damage to the brain is mediated by $T$ cells and microglia, suggesting a window for treatment if Rasmussen's encephalitis can be diagnosed early (Varadkar et al., 2014).

Although the pathologic findings often resemble that of a viral encephalitis, attempts at identifying a viral etiology have been mixed and reliable identification of an offending infectious agent has not been successful. Given the presence of autoantibodies in many cases, particularly GluR3 autoantibodies, a variety of immunotherapy treatments have been attempted with varied success (Prayson et al., 2012).

Magnetic resonance imaging (MRI) of the brain plays an essential role in the diagnosis and monitoring. The biggest change is seen early in the disease process, usually the first 8 months, consistent with acute clinical phase, and thereafter more gradual, progressive, unilateral and atrophy (Varadkar \& Cross, 2015)

\section{CASE REPORT}

A 17-month-old infant female, attended at Dr. Hospital Mario Catarino Rivas, San Pedro Sula, Honduras, from the Cordillera of the Merendón. Family history: asthmatic mother, grandfather epilepticus secondary to trauma from 20 years. Personal history: two previous admissions ( 16 months and 16 months 8 days) for convulsions for which she was admitted three days and was treated with valproic acid $30 \mathrm{mg} /$ $\mathrm{kg}$ per day. She had received all vaccinations for her age. Mother is 24 years old, first pregnancy, controlled pregnancy with an uncomplicated vaginal delivery, APGAR showed she cried at birth and anthropometry at birth is unknown. With normal neurodevelopment noted for her age.
She is received in the emergency, with a history of about three hours of evolution of tonic convulsions, focused on left side of the body with drooling, oculogyric and relaxation of sphincters, feverish $38.5^{\circ} \mathrm{C}$, weight $9.5 \mathrm{Kg}$, size $75 \mathrm{~cm}$ and PC $45 \mathrm{~cm}$, admitted as convulsive syndrome in the study, at that time because patient's convulsive episodes continued until day 30 despite treatment with valproic acid and phenobarbital, it was considered that this was a progressive myoclonus epilepsy type of Dravet Sd. Subsequently, it was deemed continuous partial convulsive syndrome because there was no loss of consciousness during seizures, and she presented up to 60 daily episodes. During her stay, she was treated with different antiepileptic drugs and antibiotic therapies due to nosocomial pneumonia and neurological etiology, continuous fever also treated with ketogenic diet, without improvement. She was presented to the neurosurgery service for surgical treatment (vrs calestomy hemispherectomy) however, because of the complexity of these treatments, a response from less invasive treatments is recommended. Progressively the patient was presenting alterations in neurodevelopment.

The electroencephalogram EEG, reported

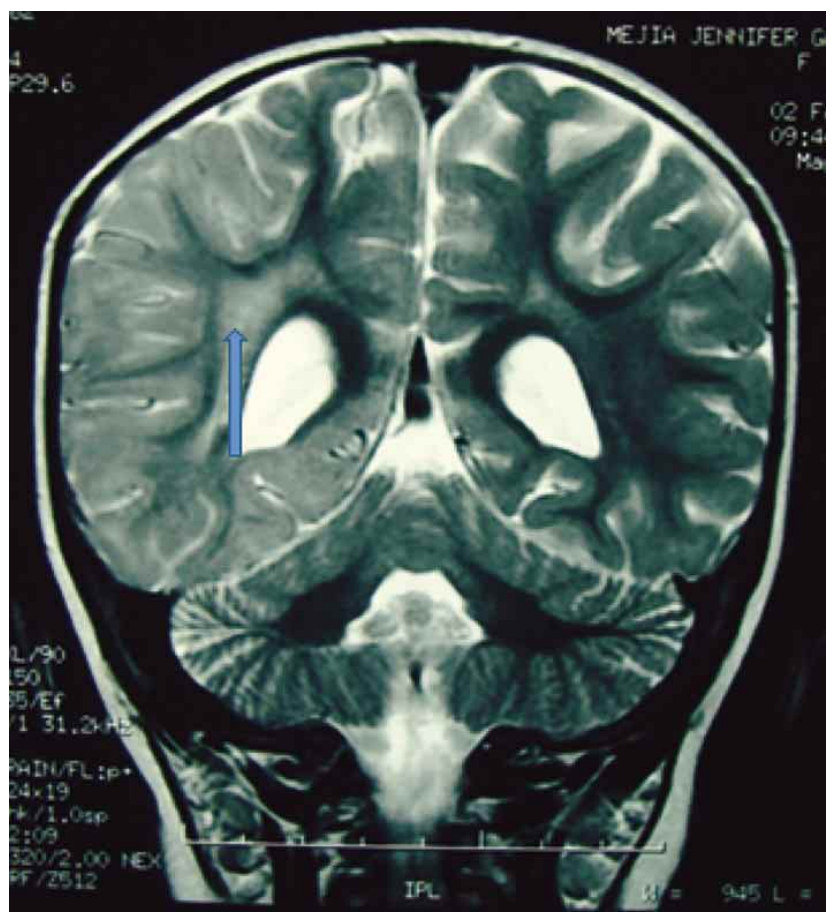

Fig. 1. The blue arrow shows the area of leukoencephalopathy. 
slow focal activity in the right hemisphere, MRI reported leukoencephalopathy of undetermined origin (Fig. 1) was performed by biopsy neuropathologist and findings consistent with reported Rasmussen syndrome (Fig. 2). She was treated with immunoglobulin every two weeks for six doses and after two months of hospitalization, she was released. Currently, episodes of seizures have decreased significantly and almost no convulsing, she does present alterations in neurodevelopment.

\section{DISCUSSION}

Rasmussen's encephalitis is a rare condition. The Montreal group estimated that this disorder accounts for up to $1 \%$ of all patients with epilepsy. The age of onset of chronic focal encephalitis ranges from 18 months to 14 years with a mean of 6.8 years, although isolated cases may occur in young adults. A non - specific infectious episode often precedes seizures in 1 to 6 months. In Honduras the first case reported in the literature was that of a child of 10 years (Osorio et al., 1997).

The key point of the clinical syndrome of Rasmussen is the continuous partial seizures. Three stages through which the disease develops are currently recognized; initially it begins with a prodrome with sporadic and hemiparesis crisis; next is the acute stage where crises are increasingly frequent addition onset of neurological impairment, as cognitive disorder, hemiparesis, hemianopia and aphasia (if the dominant hemisphere is affected) thereafter patients spend a residual phase where already they established permanent neurological deficits and crises, although less frequently than in the acute phase; although some patients will remain hemiplegic (Ornelas-Casillas \& LópezBuenrostro, 2014). The case reported in this

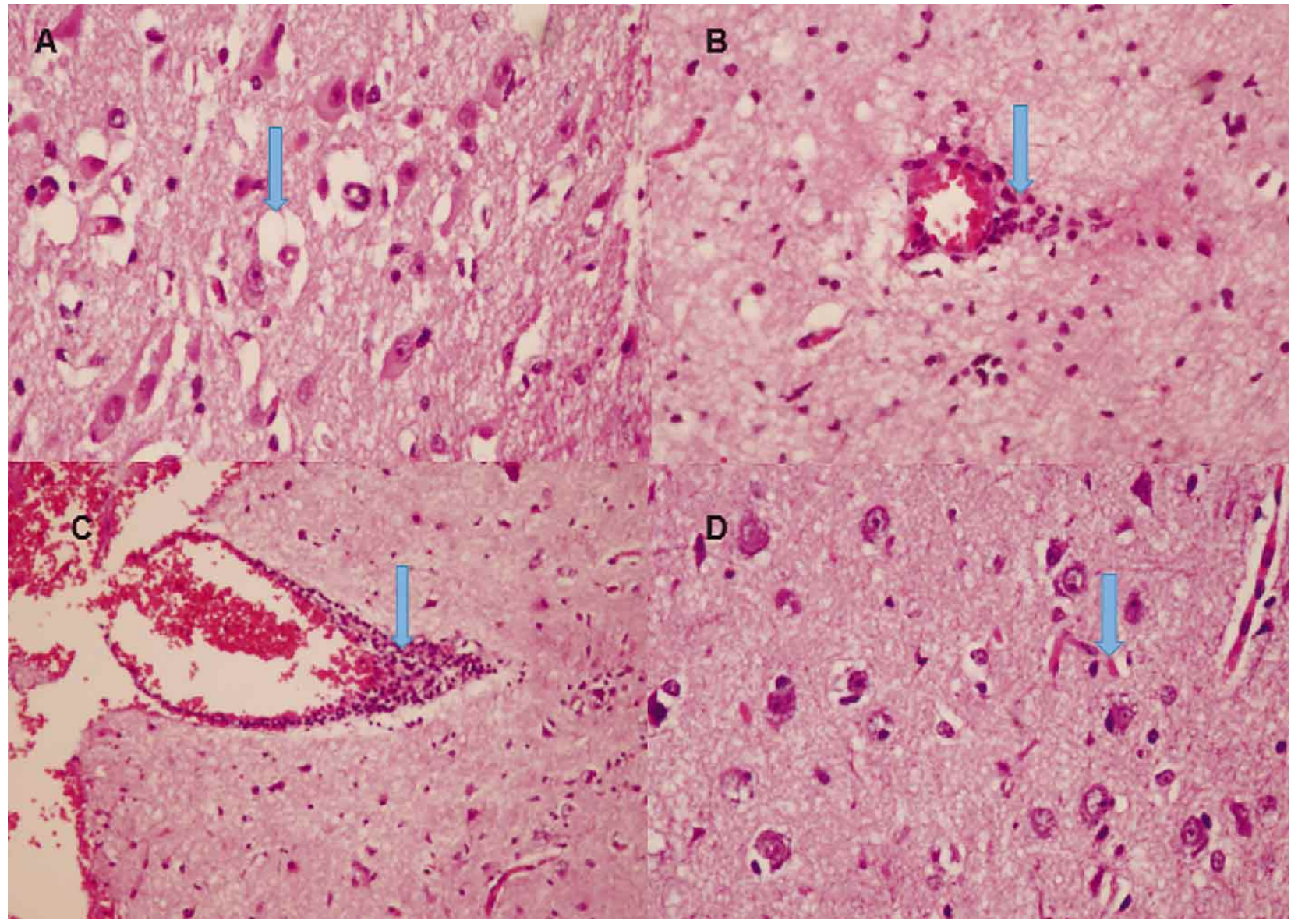

Fig. 2. A) Edema B) and C) perivascular leukocytes, D) swollen neurons. Source: biopsy of the patient by neuropathology. 
publication, was presented with a history of tonic seizure, focusing on left side of the body with drooling, oculogyros and relaxation of sphincters, feverish $38.5^{\circ} \mathrm{C}$ was admitted as convulsive syndrome in the study, then, because the patient continued with convulsive episodes up to 30 episodes per day despite treatment with valproic acid and phenobarbital, it was considered that this was a progressive myoclonus epilepsy Dravet syndrome or infant Severe Myoclonic Epilepsy type. It is a severe epileptic encephalopathy starting in the first year of life with seizures triggered by fever usually that follow a drug - resistant epilepsy. It is also known as severe myoclonic epilepsy or disease of infancy (SMEI) or polymorphous epilepsy. Its incidence is $1 / 30,000-40,000$ and represents 5 $\%$ of epilepsies debuting in the first year of life. (Pérez \& Moreno, 2015; Lopez et al., 2013). A differential diagnosis was carried out with this syndrome. Subsequently it deemed continuous partial convulsive syndrome because there was no loss of consciousness during seizures, and they presented up to 60 daily episodes. Worldwide, drug - resistant epilepsies are the biggest problem for patients with epilepsy, especially when it comes to children, being the main challenge for the professionals involved in their treatment (Campos \& Otayza, 2013).

There are several hemispheric disconnection techniques (callesetomia) for handling various pathologies that extensively compromise a cerebral hemisphere and present with refractory epilepsy to drug treatment (Vazquez et al., 2008). In this case, it was interconsulted with a neurosurgical service for surgical treatment (callosotomy hemispherectomy), however, because of the complexity of these treatments, it was recommended to wait for the results of less invasive treatments.

The diagnosis is based on brain biopsy and clinical characteristics. However, in children the diagnosis can be established on the basis of clinical features associated with magnetic resonance imaging especially showing progressive hemispheric atrophy, affecting initially perirolandic, perisylvian and frontalorbital regions (Campos et al., 2004). Magnetic resonance imaging (MRI) in combination with clinical data and focal slow activity in the EEG, contralateral to the motor manifestations may indicate the diagnosis and accelerate brain biopsy. The progression of lesions on MRI seems to reflect the course of the disease and prognosis, although the extent of the injury does not necessarily correlate with the frequency of seizures (Faria et al., 2009). In this case, the MRI reported leukoencephalopathy of undetermined origin and the EEG; slow focal activity in the right hemisphere.

Surgical specimens and biopsies show the typical encephalitis with perivascular generalized leukocytes and round cells, gliosis and scattered microglial nodules. However, the morphological image is nonspecific chronic active encephalitis. Resected specimens in advanced clinical stages have demonstrated diffuse cortical atrophy with neuronal loss and lack of inflammatory cells (Faria et al.) biopsy is of great diagnostic value. It is observed that cortical and white matter destruction, gliosis and inflammatory reaction, findings also observed in our report, so that the diagnosis was established.

Because the implications of autoimmune phenomena in the development of the disease treatments intended to modulate brain inflammatory reaction were applied, such as corticosteroids, immunoglobulins, plasmapheresis or interferon, with good results in some cases, but always characterized by the disappearance of effect on withdrawal of treatment. At the Ramon y Cajal in Madrid Spain Hospital, a case of Rasmussen disease with positive anti-GAD diagnosed in very early stages was described, allowing a stable remission after treatment with intravenous gamma globulin and corticosteroids and represents the first case in the medical literature as favorable evolution. (Carrillo Herranz et al., 2003) In the present case treated with immunoglobulin every two weeks for six doses, with good response to treatment.

\section{CONCLUSION}

When we are facing a previously healthy, especially pediatric patient with drug - resistant convulsive syndrome, focal seizures and impaired neurodevelopmental must be considered suspect in the ER. 
ACKNOWLEDGEMENTS. Dr. Ricardo Madrid neuropathologist University Teaching Hospital, Tegucigalpa Honduras, having performed the biopsy of the patient and provide images for this publication.

DISCLOSURE OF CONFLICT OF INTEREST. The authors report no conflicts of interest in this work.

LICONA, R. T. S.; MAZARIEGOS-RIVERA, A. \& MEDINA, M. Encefalitis de Rasmussen. Reporte de caso. Int. J. Med. Surg. Sci., 3(2):849-854, 2016.

RESUMEN: La encefalitis de Rasmussen (ER) es un trastorno poco frecuente pero grave, mediado inmunológicamente, que afecta al cerebro y conduce a la atrofia hemisférica unilateral, disfunción neurológica progresiva asociada con deterioro intelectual y convulsiones intratables. Lactante de 17 meses de edad, atendida en el Hospital MarioCatarino Rivas, Honduras. Con antecedentes familiares: abuelo epiléptico secundario a trauma a partir de los 20 años. Antecedentes personales: dos ingresos previos por cuadros convulsivos por los cuales estuvo ingresada tres días, en tratamiento con ácido valproico $30 \mathrm{mg} /$ $\mathrm{kg}$ por día. Es recibida en la emergencia, con historia de aproximadamente tres horas de evolución de convulsiones tónicas, focalizadas en hemicuerpo izquierdo con sialorrea, oculogiros y relajación de esfínteres, febril $38,5^{\circ} \mathrm{C}$. Ingresada como síndrome convulsivo en estudio, sin embargo, al pasar los días incrementó el número de convulsiones hasta 60 diarios y progresivamente fue presentando alteraciones en su neurodesarrollo. La Resonancia Magnética reportó leucoencefalopatia de origen no determinado y la biopsia reportó hallazgos compatibles consíndrome de Rasmussen. Fue tratada con inmunoglobulina cada quince días por seis dosis y después de dos meses de hospitalización, se logró egresar. Actualmente, los episodios de convulsiones han disminuido considerablemente y casi no convulsiona, presenta alteraciones en su neurodesarrollo.

PALABRAS CLAVE: Biopsia; Encefalitis; Epilepsias parciales; Convulsiones.

\section{REFERENCES}

Campos, P. N. A.; Cárdenas, M. E.; Riestra, R. A.; Sánchez, C. J.; Favila, H. R.; Hernández, T. A. \& Salgado, L. P. Estudio en un paciente con síndrome de Rasmussen utilizando resonancia magnética convencional y funcional mediante la técnica Bold. An. Radiol. Méx., 3(1):39-42, 2004.
Campos P., M. \& Otayza M., F. Consideraciones quirúrgicas propias de la epilepsia en niños. Rev. Med. Clin. Condes, 24(6):1019-26, 2013.

Carmona-Vázquez, C. R.; Peña-Landín, D. M.; VenzorCastellanos, J. P.; Pasquel García Velarde, P. M. \& Dávila-Gutiérrez, G. Encefalitis de Rasmussen: Complejidad del manejo de una epilepsia potencialmente farmacorresistente ilustrada por dos casos clínicos potencialmente farmacorresistente ilustrada por dos casos clínicos. Rev. Mex. Neurocienc., 15(2):119-24, 2014.

Carrillo Herranz, A. ; Sánchez Pérez, I. ; Aparicio Meix, J. M.; Lozano Giménez, C. ; Roy Ariño, G.; Villar Gimerans, L. M. \& Sánchez Muñoz, L. Síndrome de Rasmussen: una enfermedad autoinmune. $A n$. Pediatr. (Barc.), 59(2):187-9, 2003.

Faria, A: V.; Reis, F.; Dabus, G. C.; Zanardi, V. A.; Guerreiro, M. M. \& Cendes, F. MRI findings in the diagnosis and monitoring of rasmussen's encephalitis. Arq. Neuropsiquiatr., 67(3b):792-7, 2009.

López S., I. M.; Varela E., X. \& Marca G., S. Sindromes epilépticos en niños y adolescentes. Rev. Med. Clin. Condes, 24(6):915-27, 2013.

Osorio, J. R.; Medina, M. T.; Durón, R.; Bu, J.; Sánchez, J. \& Madrid L., R. Encefalitis crónica focal de Rasmussen: Reporte de caso. Rev. Hondur. Neurocienc., 1(1), 1997

Ornelas-Casillas, M. A. \& López-Buenrostro, S. A. Síndrome de Rasmussen, una encefalitis autoinmune de difícil control: el tratamiento quirúrgico como última alternativa. Rev. Med. MD, 6(1):84-7, 2014.

O'Rourke, D. J.; Bergin, A.; Rotenberg, A.; Peters, J.; Gorman, M.; Poduri, A. ; Cryan, J.; Lidov, H. ; Madsen, J. \& Harini, C. Rasmussen's encephalitis presenting as focal cortical dysplasia. Epilepsy Behav. Case Rep., 2:86-9, 2014.

Pardo, C. A.; Nabbout, R., \& Galanopoulou, A. S. Mechanisms of epileptogenesis in pediatric epileptic syndromes: Rasmussen encephalitis, infantile spasms, and febrile infection-related epilepsy syndrome (FIRES). Neurotherapeutics, 11(2):297-310, 2014.

Pérez, A. B. \& Moreno, N. Síndrome de Dravet. Salus, 19(3):27-30, 2015.

Prayson, R. A. Dual Pathology in Rasmussen's Encephalitis: A Report of Coexistent Focal Cortical Dysplasia and Review of the Literature. Case Rep. Pathol., 2012:569170, 2012. 
LICONA, R. T. S.; MAZARIEgOS-RIVERA, A. \& MEDINA, M. Rasmussen's encephalitis. A case report. Int. J. Med. Surg. Sci., 3(2):849-854, 2016.

Varadkar, S.; Bien, C. G.; Kruse, C. A.; Jensen, F. E.; Bauer, J.; Pardo, C. A.; Vincent, A.; Mathern, G. W. \& Cross, J. H. Rasmussen's encephalitis: clinical features, pathobiology, and treatment advances. Lancet Neurol., 13(2): 195-205, 2014.

Varadkar, S. \& Cross, J. H. Rasmussen syndrome and other inflammatory epilepsies. Semin. Neurol., 35(3):259-68, 2015.

Vázquez, C.; Leonardo de, J. B.; Bartuluchi, M.; Medina, C.; Petre, C. \& Pomata, H. Hemisferectomías y hemi-hemisferectomías: nuestra experiencia acerca de 49 casos. Rev. Argent. Neurocir., 22(3):131-3, 2008.
Correspondence to:

Tania Soledad Licona Rivera

Doctora en Medicina General y Cirugía

Especialidad en Pediatría

Universidad Nacional Autónoma de Honduras en el Valle de Sula

San Pedro Sula

HONDURAS

Tel: (504)97101318

Email: Tania.licona@unah.edu.hn

Received: $18-05-2016$

Accepted: 18-06-2016 